\title{
A Study of Giant Cell Lesions of Bone
}

\author{
Faruq Ibrahim Mulla ${ }^{1 *}$, Cherry K. Shah ${ }^{2}$ And Nailesh R. Shah ${ }^{2}$ \\ 'Pramukh Swami Medical College, Shree Krishna Hospital Karamsad, Gujarat, India \\ ${ }^{2}$ Smt. N.H.L. Municipal Medical College, Seth KM School Of Postgraduate Medicine And Research, Ahmedabad, Gujarat, India
}

\section{ABSTRACT}

Introduction: Giant cell lesions of bone include true giant cell tumors \& numerous benign osteoclasts and pseudo-anaplastic-appearing giant cells containing variants. Many times it is difficult to differentiate between true giant cell tumor and other tumor like conditions.

Aims: To study histopathology of various giant cell rich tumour and tumour like conditions of bone.

Methods: Retrospective analysis of 50 cases of giant-cell rich lesions of bone diagnosed and treated at Smt. N.H.L. Municipal Medical College Ahmedabad, Gujarat during 1st January 2002 to 1st January 2003 included in the study. Patients' clinical, radiological details, histopathological examination were studied using structured proforma. The cases were classified in different categories according to age groups, types of tumour, benign versus malignant category.

Results: The most common giant cell containing benign tumor is giant cell tumor (19 cases) followed by Aneurysmal bone cyst (5), Most of the giant cell containing tumors of bone are found in younger age group and are located in epiphysis The common giant cell containing malignant tumor is osteogenic sarcoma ( 7 cases) followed by Talangiectatic O.S (01). The majority of cases found in age between 15 - 28 years and most common sites are epiphysis of long bones.

Conclusion: The most common giant cell rich benign bone tumour is giant cell tumour and most common giant cell rich malignant bone tumour is osteosarcoma commonly occurs in younger age groups in the epiphysis region long bones.

\section{Keywords: Osteoclast, Giant cell, Malignant}

\section{Introduction}

Giant cell lesions of bone include true giant cell tumors \& numerous benign as well as malignant conditions having osteoclasts and pseudo-anaplastic-appearing giant cells containing variants ${ }^{[1]}$ The approach to any bony lesion should be established by clinical, radiological and pathological investigations, supplemented when necessary by biochemical and hematological studies ${ }^{[2]}$ The five basic parameters of importance are the age of the patient, bone and specific areas involved within the bone, radiographic appearance and microscopic appearance. Histological study is essential for the precise diagnosis of bony lesions. It usually involves examinations of a biopsy specimen, either open surgical biopsy or needle biopsy. In this study, true giant cell tumor as well as other giant cell containing bony lesions are included. ${ }^{[3]}$

Osteoclast like giant cells may dominate the histological pattern not only in the giant cell tumour but also a variety of bone lesions namely aneurysmal bone cyst, giant cellrich osteosarcoma, chondroblastoma ${ }^{[4]}$

Most of these occurs in adult life ( $\left.2^{\text {nd-3rd }} d e c a d e\right)$, except for giant cell tumour and chondroblastoma. In young patient, chondroblastoma and in patient older than 20 years, giant cell tumor should be included in differential diagnosis. ${ }^{[5]}$

However, to avoid confusion and to reach to a definitive diagnosis in such cases, it is necessary to take into account histological features, Clinico- radiologic correlation, and age of patient and site of lesions. ${ }^{[6]}$

\section{Material and Methods}

A retrospective study of 50 cases of giant cell rich lesions was done. Each case was investigated according to age, sex, clinical examination \& type of specimen. Radiological findings ( $\mathrm{X}$ ray, CT scan, MRI, etc.) of all patients are obtained from patient medical records. The specimens \& biopsies were fixed in $10 \%$ neutral formalin, bony bits transferred to a large volume of $10 \%$ nitric acid, decalcified and after proper decalcification embedded in paraffin wax, stained with Haematoxylin and eosin (H \& E) \& mounted with DPX which were examined for growth pattern, cell size, cell shape, nuclear characteristics, pleomorphism, mitosis, stroma \& necrosis.

The cases categorized into different groups according to age, sex, site of origin, type and benign versus malignant categories. 


\section{Results}

Most of the giant cell containing tumors of bone is found in younger age group in second and third decade while aneurysmal bone cyst is found in third and fourth decade. Most of the giant cell tumors are found between 15 to 40 years of age.

In present study, giant cell tumor of bone is located in epiphysis in most of the cases. Aneurysmal bone cyst is located in the epiphysis as well as metaphysis of long bones. Telangiectatic osteosarcoma is located near shaft of long bones. Langerhan's cell histiocytosis is located in the skull. Chondromyxoid fibroma has been detected in small bones of hands and foot.
The osteoclastoma is maximum of all benign lesions.

Statistical analysis: $T$ test between age and type of lesion has been applied The mean for benign giant cell leson is 24.21 and for malignant tumor the mean is 19.50 . There is no statistical significant difference seen between the ages and the nature of lesion (Table-1)

The giant cell tumor of bone and other giant cell rich lesions of bone are is more common in male. (Table $-2 \&$ Table 3 )

The giant cell rich lesion are most common in tibia 17(34.0) followed by femur 14(28.0) Fishers exact test $=5.821, \mathrm{p}$ value $=1.00$ (Table-4) According to present study, the most common giant cell rich lesion is true giant cell tumor (19) followed by osteosarcoma (07) (Table-5)

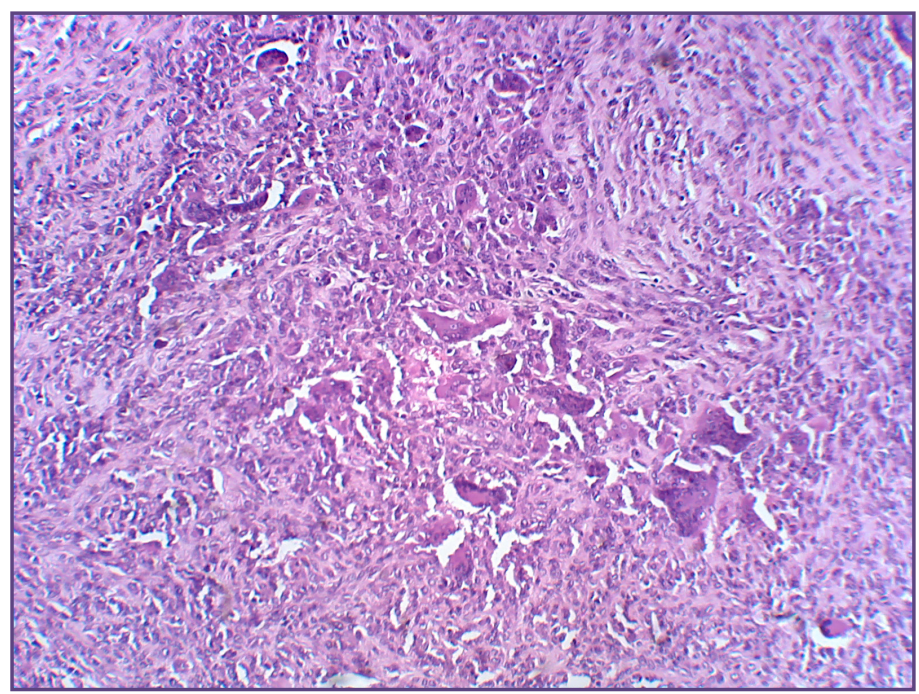

Fig. 1: shows numerous giant cells in Giant cell tumor of bone (Low power view)

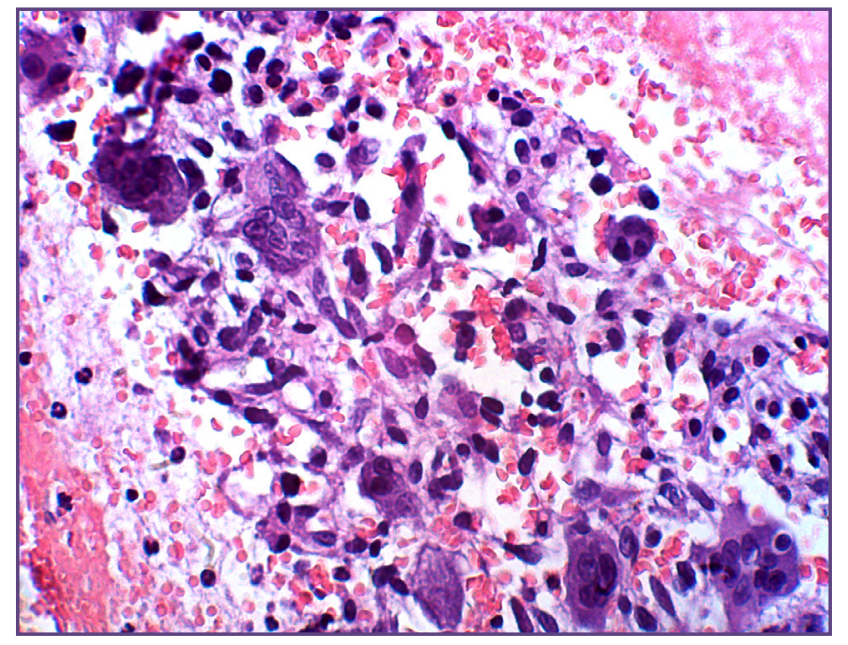

Fig. 2: Shows giant cells in wall of Aneurysmal bone cyst fillwd with RBC (High Power)

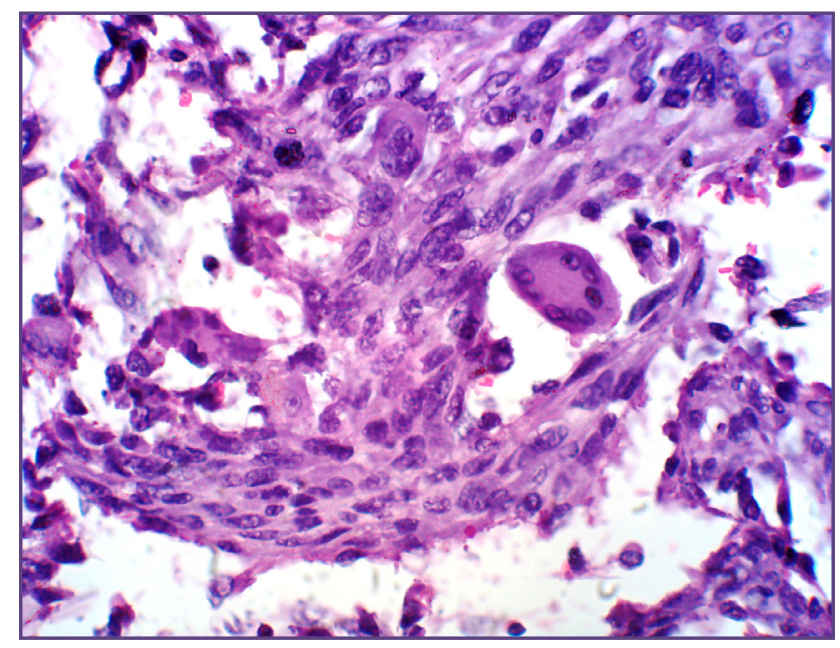

Fig. 3: Shows spindle shaped tumor cells with giant cells in Osteosarcoma (high power) 
Table 1: Shows T test between age and type of lesion

\begin{tabular}{|c|c|c|c|c|}
\hline Nature of lesion & N & Mean & Std. Deviation & Std. Error Mean \\
\hline Benign & 42 & 24.21 & 12.436 & 1.919 \\
\hline Malignant & 8 & 19.50 & 5.182 & 1.832 \\
\hline
\end{tabular}

There is no statistical significant difference seen between the ages and the nature of lesion

Table 2: Sex wise distribution of giant cell rich lesion

\begin{tabular}{|c|c|c|c|}
\hline \multirow{2}{*}{ Bone } & \multicolumn{2}{|c}{ Sex } & \multirow{2}{*}{ Total } \\
\cline { 2 - 4 } & Female & $3(60.0)$ & $5(100.0)$ \\
\hline Aneurysmal bone cyst & $2(40.0)$ & $1(100.0)$ & $1(100.0)$ \\
\hline Chondroblastoma & $0(0.0)$ & $1(100.0)$ & $1(100.0)$ \\
\hline Chondromyxoid fibroma & $0(0.0)$ & $2(100.0)$ & $2(100.0)$ \\
\hline Eosinophilic granuloma & $0(0.0)$ & $10(52.6)$ & $19(100.0)$ \\
\hline Giant cell tumor & $9(47.4)$ & $1(100.0)$ & $1(100.0)$ \\
\hline Langerhans' cell histiocytosis & $0(0.0)$ & $3(60.0)$ & $5(100.0)$ \\
\hline Nonossifying fibroma & $2(40.0)$ & $3(100.0)$ & $7(100.0)$ \\
\hline Osteogenic sarcoma & $0(0.0)$ & $3(60.0)$ & $5(100.0)$ \\
\hline Osteoid Osteoma & $2(40.0)$ & $1(66.7)$ & $3(100.0)$ \\
\hline Simple bone cyst & $1(33.3)$ & $34(68.0)$ & $1(100.0)$ \\
\hline Telangiectatic osteosarcoma & $0(0.0)$ & $16(32.0)$ & $50(100.0)$ \\
\hline
\end{tabular}

Fisher's Exact Test $=8.844 p=0.566$

Table 3: Sex wise distribution of benign and malignant lesion

\begin{tabular}{|c|c|c|c|}
\hline \multirow{2}{*}{ Nature of lesion } & \multicolumn{2}{|c|}{ Sex } & \multirow{2}{*}{ Total } \\
\cline { 2 - 4 } & Female & $26(61.9)$ & $42(100.0)$ \\
\hline Benign & $16(38.1)$ & $8(100.0)$ & $8(100.0)$ \\
\hline Malignant & $0(0.0)$ & $34(68.0)$ & $50(100.0)$ \\
\hline Total & $16(32.0)$ & & \\
\hline
\end{tabular}

Fisher's Exact Test $p=0.043$; The difference is significant

Table 4: Shows location of bone of giant cell rich lesion

\begin{tabular}{|c|c|c|c|}
\hline \multirow{2}{*}{ Bones involved } & \multicolumn{2}{|c|}{ Nature of lesion } & \multirow{2}{*}{ Total } \\
\cline { 2 - 4 } & Benign & $0(0.0)$ & $1(2.0)$ \\
\hline Calcaneum & $1(2.4)$ & $3(37.5)$ & $14(28.0)$ \\
\hline Femur & $11(26.2)$ & $0(0.0)$ & $1(2.0)$ \\
\hline Fibula & $1(2.4)$ & $0(0.0)$ & $1(2.0)$ \\
\hline Frontal & $1(2.4)$ & $2(25.0)$ & $8(16.0)$ \\
\hline Humerus & $6(14.3)$ & $0(0.0)$ & $1(2.0)$ \\
\hline MC Bone & $1(2.4)$ & $0(0.0)$ & $1(2.0)$ \\
\hline Phalanx & $1(2.4)$ & $0(0.0)$ & $3(6.0)$ \\
\hline Radius & $3(7.1)$ & $0(0.0)$ & $1(2.0)$ \\
\hline Sacrum & $1(2.4)$ & $0(0.0)$ & $1(2.0)$ \\
\hline Skull & $1(2.4)$ & $3(37.5)$ & $17(34.0)$ \\
\hline Tibia & $14(33.3)$ & $0(0.0)$ & $1(2.0)$ \\
\hline Ulna & $1(2.4)$ & $8(100.0)$ & $50(100.0)$ \\
\hline Total & $42(100.0)$ & & \\
\hline
\end{tabular}

Fishers exact test $=5.821, p$ value $=1.00$ 
Table 5: Shows distribution of giant cell rich lesions

\begin{tabular}{|c|c|c|c|}
\hline \multirow{2}{*}{ Histopathological Diagnosis } & \multicolumn{2}{|c|}{ Nature of lesion } & \multirow{2}{*}{ Total } \\
\cline { 2 - 4 } & Benign & Malignant & $0(0.0)$ \\
\hline Aneurysmal bone cyst & $5(11.90)$ & $0(0.0)$ & $1(2.0)$ \\
\hline Chondroblastoma & $1(2.3)$ & $0(0.0)$ & $1(2.0)$ \\
\hline Chondromyxoid fibroma & $1(2.3)$ & $0(0.0)$ & $2(4.0)$ \\
\hline Eosinophilic granuloma & $2(4.6)$ & $0(0.0)$ & $19(38.0)$ \\
\hline Giant cell tumor & $19(45.23)$ & $0(0.0)$ & $1(2.0)$ \\
\hline Langerhans' cell histiocytosis & $1(2.3)$ & $0(0.0)$ & $5(10.0)$ \\
\hline Nonossifying fibroma & $5(11.90)$ & $7(87.5)$ & $7(14.0)$ \\
\hline Osteogenic sarcoma & $0(0.0)$ & $0(0.0)$ & $5(10.0)$ \\
\hline Osteoid Osteoma & $5(11.90)$ & $0(0.0)$ & $3(6.0)$ \\
\hline Simple bone cyst & $3(7.14)$ & $1(12.5)$ & $1(2.0)$ \\
\hline Telangiectatic osteosarcoma & $0(0.0)$ & $8(100.0)$ & $5(100.0)$ \\
\hline Total & $42(100.0)$ & & \\
\hline
\end{tabular}

\section{Discussion}

The diagnosis of giant cell-rich lesions of bone is often problematic even for the experienced pathologist. The diagnostic key lies in multinucleated osteoclast-like giant cells and a mononuclear stroma. ${ }^{[7]}$ From the histological picture alone it is often difficult to distinguish between individual entities such as conventional giant-cell tumor of bone, non-ossifying fibroma, giant-cell tumor in hyperparathyroidism or an aneurysmal bone cyst. ${ }^{[8]}$

Total 50 bone lesions were studied and divided into benign and malignant tumors. The incidence of true giant cell tumor (osteoclastoma) is maximum of all lesions in present study which is higher than Goldenberg and Dahlin et al. ${ }^{[9]}$ Although giant cell tumor is considered as potentially malignant tumor, it is considered in benign because all giant cell tumors in this study show no atypical features in stroma. ${ }^{[10]}$ Most of the giant cell containing tumors of bone are found in younger age group in second and third decade between 15 to 40 years of age while aneurysmal bone cyst is found in third and fourth decade. ${ }^{[11]}$ In present study, giant cell tumor of bone is located in epiphysis in most of the cases. Giant cell tumors have higher incidence in male population in present study. Aneurysmal bone cyst is more common in males in the present study. Aneurysmal bone cyst is located in the epiphysis as well as metaphysis of long bones. According to Modi et al ${ }^{[12]}$ osteoclast like giant cells may dominate the histologic pattern not only in the giant cell tumor but also a variety of bone lesions namely aneurysmal bone cyst, giant cell-rich osteosarcoma, chondroblastoma, giant cell reparative granuloma and fibrous dysplasia.
Most of these occurs in adult life (2nd -3rd decade), except for giant cell tumor and chondroblastoma, Giant cell-rich lesions don't affect the epiphysis on primarily level. In young patient, chondroblastoma and in patient older than 20 years, giant cell tumor should be included in differential diagnosis.

According to Modi et al, the giant cell rich lesion of bone inclides giant cell tumour of bone (41), aneurysmal bone cyst (04), giant cell-rich osteosarcoma (02), giant cell reparative granuloma (02), and fibrous dysplasia (01) noted at their institute. While in present study, the giant cell rich lesions includes giant cell tumor (19 cases), Aneurysmal bone cyst (5), osteogenic sarcoma (7 cases) and Talangiectatic osteosarcoma (01). Most of the giant cell containing tumors of bone are found in younger age group and are located in epiphysis The majority of cases found in age between 15 - 28 years and most common sites are epiphysis of long bones.

According to Kumavat et al ${ }^{[13]}$ out of 216 cases of bone tumors Out of 216 cases, primary bone tumors were 151 (69.91\%), metastatic tumors were 40 cases $(18.52 \%)$ and tumor like conditions were 25 cases (11.58\%). According to Sunita

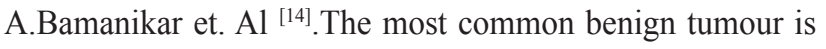
osteochondroma followed by giant cell tumour of all benign tumours. osteosarcoma is commonest malignant tumour.

\section{Conclusion}

Detailed histopathological study and clinico-radiological correlation is very helpful to arrive at precise and accurate diagnosis in giant cell rich lesions. The common giant cell rich bone lesion are true giant cell tumor 
(osteoclastoma) and osteosarcoma which is common in younger age group.

\section{References}

1. Zhang Y, Rosenberg AE, Layfield LJ, Nielsen GP. Neoplastic and tumor-like lesions of bone. In: Mark R. Wick, Virginia A. LiVolsi, John D. Pfeifer, Edward B. Stelow, Paul E. Walkely editors. Silverberg's Principles and Practice of Surgical Pathology and Cytopathology, Fifth ed. Cambridge: University Press;2006.1007-1123.

2. Chakarun CJ, Forrester DM, Gottsegen CJ, Patel DB, White EA, Matcuk GR, Jr, Giant Cell Tumor of Bone: Review, Mimics, and New Developments in Treatment, RadioGraphics 2013; 33:197-211.

3. Athanasou NA, Bansal M, Forsyth R, et al. Giant cell tumour of bone. In: Fletcher CD, Bridge JA, Hogendoorn PC, eds. WHO Classification of tumour of soft tissues. Lyon, France: IARC Press 2013; 321-324

4. Flanagan AM, Tirabosco R, Gikas PD. Osteoclast-rich lesions of bone: a clinical and molecular overview. In: $\mathrm{D}$ ominique $\mathrm{H}$ eymann editor. Bone Cancer, $2^{\text {nd }}$ ed. San Diego, USA: Elsevier; 2015. p. 257-272.

5. Gupta R, Seethalakshmi V, Jambhekar NA, et al. Clinicopathologic profile of 470 giant cell tumours of bone from a cancer hospital in western India. Ann Diagn Pathol 2008;12(4):239-248.

6. Cowman RW, Singh G. Giant cell tumor of bone: a basic science perspective. Bone 2013;52:238-246

7. Horvai A. Bones, joints and soft tissue tumours. In: Kumar V, Abbas AK, Fausto N, Aster JC, editors. Robbins and cotran; Pathologic Basis of disease. $9^{\text {th }}$ ed. Philadelphia: Elsevier, Saunders; 2015. p.1180-1224.

8. Rosenberg A.E., Nielsen G.P. Giant cell containing lesions of bone and their differential diagnosis. Diagn Histopathol 2001;7(4):235-246

9. Goldenberg RR, Campbell CJ, Bonfiglio M. Giant-cell tumour of bone. An analysis of 218 cases. J Bone Joint Surg Am 1970;52(4):619-663.

10. Balke M, Schremper L, Gebert C, Ahrens H, Streitbuerger A, Koehler $\mathrm{G}$ et al. Giant cell tumor of bone: treatment and outcome of 214 cases. J Cancer Res Clin Oncol 2008;134:969-978.

11. Zheng $\mathrm{MH}$, Robbins $\mathrm{P}, \mathrm{Xu} \mathrm{J}$, Huang L, Wood DJ, Papadimitriou JM. The histogenesis of giant cell tumour of bone: a model of interaction between neoplastic cells and osteoclasts. Histol Histopathol 2001;16(1):297-307.

12. Modi VM, Modi MB, Jetly DH, Mehta SP, Kundariya M, et al. Primary Giant Cell-Rich Lesions of Bone with Role of Denosumab - Histopathological Study with ClinicoRadiological Correlation. Int Clin Pathol J 3(1): 00066. DOI: 10.15406/icpj1.2016.03.00066

13. Kumavat PV, Gadgil NM, Chaudhari CS, Rathod UK, Kshirsagar GR, Margam SS. Bone Tumors and Tumor-like lesions: A study in A Tertiary Care Hospital, Mumbai. Ann Lab Med 2017;4(1):A-11-18

14. Bamanikar SA, Pagaro PM, Kaur P, Chandanwale SS, Bamanikar A, Buch AC. Histopathological Study of Primary Bone Tumours and Tumour-Like Lesions in a Medical Teaching Hospital. JKIMSU 2015;4(2):46-55.

*Corresponding author:

Dr. Faruq Ibrahimbhai Mulla, 17, Ellora Park Society, 100 Feet Road, Near Royal Plaza, Anand, 388001, State- Gujarat, India

Phone: +919601275298

Email: drfm24@gmail.com

Date of Submission : 25.05.2017

Date of Acceptance : 24.06.2017

Financial or other Competing Interests: None. 